\title{
Kaum Arab Hadrami Dalam Sejarah Perkembangan Lembaga Pendidikan Al Irsyad (1918-1950)
}

\author{
Samudra Eka Cipta \\ Program Sarjana Departemen Pendidikan Sejarah, Universitas Pendidikan Indonesia
}

\begin{tabular}{|c|c|}
\hline Article Info & ABSTRACT \\
\hline Article history: & \multirow{14}{*}{$\begin{array}{l}\text { The research seeks to examine how the role of Arab descendants in developing } \\
\text { an education system that is oriented towards the state and religion. The } \\
\text { division of the Arab descendants between the pro against the idea of } \\
\text { nationalism with groups opposing nationalism was established by the Al- } \\
\text { Irshad Educational Institute which was aimed at advancing the educational } \\
\text { needs of the indigenous people and the Arab descendants. Important figures in } \\
\text { the founding of the Al-Irsyad Institute such as Abdul Rahman Baswedan and } \\
\text { Ahmad Sukrati succeeded in forming a generation that would later fight for } \\
\text { Indonesian Independence through educational institutions. Before the } \\
\text { formation of the Al-Irshad Educational Institution there were differences of } \\
\text { opinion among fellow Arab Descendants Community Group Jami'at Kheir had } \\
\text { already been established but some members wanted the importance of } \\
\text { education for the natives and descendants, so some members of the former } \\
\text { Jam'at Kheir then established the Educational Institution Al-Irshad. This study } \\
\text { uses a socio-historical approach by having the formulation of problems } \\
\text { including, 1) how did the social conditions of the Arab Descendants start in } \\
\text { Indonesia, 2) how did the establishment of the Al-Irshad Educational } \\
\text { Institution start and, 3) how was the role of the Al-Irshad Educational } \\
\text { Institution? }\end{array}$} \\
\hline Received 2020-02-31 & \\
\hline Accepted 2020-04-06 & \\
\hline & \\
\hline Keywords: & \\
\hline Al-Irsyad & \\
\hline Arab & \\
\hline Hadrami & \\
\hline Sejarah & \\
\hline & \\
\hline & \\
\hline & \\
\hline & \\
\hline & \\
\hline
\end{tabular}

This is an open access article under the CC BY-SA license.

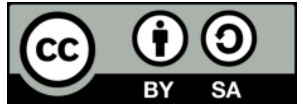

\section{Corresponding Author:}

Samudra Eka Cipta

Program Sarjana Departemen Pendidikan Sejarah, Universitas Pendidikan Indonesia

E-mail: Samudraeka97@gmail.com

\section{PENDAHULUAN}

Keturunan Arab Hadrami sudah lama telah menetap di Hindia Belanda sejak Abad ke-13 Masehi. Diaspora Keturunan Arab Hadrami dilakukan sampai Abad ke-19 sebagai diaspora terakhir kaum Hadrami ke Indonesia. Namun, lama-kelamaan mereka sering menetap di wilayah Sriwijaya karena dana terbatas, dan Komunitas Arab Hadrami (Hadramaut) menjadi kelompok pertama yang berhenti dan menetap di Indonesia. Bukan hal yang aneh bagi Komunitas Arab Hadrami untuk akhirnya berbaur dengan orang Indonesia asli dan membentuk kelompok komunitas baru, 'Arab Peranakan'. Sedangkan kelompok masyarakat Hadrami lainnya yang memelihara keturunan mereka membentuk kelompok 'Arab Totok atau Sayid Arab'. Maka dari itu A.R Baswedan sebagai pemilik darah keturunan Arab merasakan perlunya persatuan di antara orang Arab baik peranakan maupun totok (Djoened, dkk. 1992, hlm. 227).

Kaum Arab Hadrami mendirikan kampung-kampung dan syarikat-syarikat yang semula untuk mengingatkan kehadiran mereka tentang asal usul nenek moyangnya. Sebelum didirikannya Al-Irsyad didirikannya juga Jami'at Al-Khairiyyah atau Jamiat Kheir yang bergerak pada bidang pendidikan. Metode pendidikan yang diajarkan adalah metode wathoniyyah yang artinya mengajarkan cinta tanah air dalam konteks wilayah Hadramaut Yaman. Semenjak munculnya Organisasi Al-Irsyad maka terjadinya persaingan antara Jamiat Kheir dan Al-Irsyad. Perbedaan diantara kedua organisasi tersebut terletak pada 
perbedaan orientasi. Meskipun Al-Irsyad secara praktik pendidikan mengikuti gaya Jamiat Kheir akan tetapi perbedaannya adalah Al-Irsyad sangat mengedepankan praktik pembelajaran yang merdeka.

Tentunya Al-Irsyad sangat mengedepankan prinsip toleransi dalam proses pembelajaran nya, secara definitif penerapan toleransi dalam pendidikan sangat mengacu kepada tingkat keadilan atau praktik yang setara terhadap aturan pendidikan yang diterapkan oleh Al-Irsyad untuk menjamin kebebasan hak-hak kebebasan Individu dalam konteks sebagai pelajar Al-Irsyad. Hal ini terbukti ketika Al-Irsyad membuka diri untuk menerima keanggotaan dan pelajar yang bukan berasal dari Non-Hadrami seperti penduduk Pribumi yang diperbolehkan untuk belajar bahkan menjadi pimpinan cabang daerah yang dikembangkan oleh Al-Irsyad.

\section{METODE}

Data yang diolah berdasarkan dengan studi kepustakaan yakni dengan menggunakan berbagai macam sumber literasi yang mendukung dalam kajian ini. Sumber-sumber yang digunakan menggunakan buku, jurnal, penelitian terdahulu, dan beberapa sumber internet yang dapat dipertanggungjawabkan. Menggunakan pendekatan kualitatif artinya kajian ini ditulis berdasarkan penggambaran deskriptif dari sumber yang didapatkan. Juga menggunakan metodologi historis sebagai pengembangan kajian.

Penulis juga menggunakan pendekatan metode penulisan sejarah yakni dimulai dari heuristik, kritik, interpretasi, dan historiografi. Heuristik (Ismaun, dkk. 2006, hlm. 20) adalah kegiatan yang berkaitan dengan proses pencarian dan pengumpulan sumber sejarah serta penggunaan metode studi konten isi yakni dengan menggunakan pendekatan studi literatur dari beberapa sumber dengan mengkaji beberapa temuan berupa pengumpulan buku-buku sebagai sumber referensi sekaligus pembanding sumber pada pembahasan ini. Dengan kata lain, metode penelitian sejarah adalah instrumen untuk merekonstruksi peristiwa sejarah (sejarah sebagai aktualitas masa lalu) ke dalam sejarah sebagai cerita (sejarah sebagaimana ditulis). Dalam lingkup Ilmu Sejarah, metode penelitian ini disebut metode historis.

\section{HASIL DAN PEMBAHASAN}

\section{Kehidupan Awal Masyarakat Keturunan Arab Hadrami di Indonesia}

Masyarakat Keturunan Arab Hadrami sudah melakukan diaspora pada Abad ke-8 sampai ke-9 Masehi. Faktor yang menyebabkan para keturunan Arab melakukan diaspora secara besar-besaran dikarenakan pada saat itu mereka menjadi ancaman bagi kekuatan politik Ummayad, banyak golongan sayyid yang dibunuh bahkan melakukan pengejaran hingga wilayah Bagian Selatan Arab (Yaman). Terdapat arus diaspora dua kelompok yang berbeda yakni melalui darat dan melalui laut. Orang-orang Keturunan Sayyid yang berdiaspora melalui darat mereka berdiaspora hingga ke wilayah Afrika Timur sedangkan yang melakukan perjalanan melalui laut mereka sampai ke India. Sesampainya di India mereka melakukan aktiftitas perdagangan di pesisir Barat India mulai dari sepanjang Karachi hingga sampai ke Gujarat sebagai pusat perdagangan bagi perekonomian Muslim (Isnaeni, 2019).

Ketika sesampainya di Indonesia Kaum Arab Hadrami melakukan perdagangan di Indonesia dan menetap dalam jangka waktu yang lama. Keturunan Arab Hadrami mulai membuka hubungan perdagangan dengan kerajaan Sriwijaya sebagai pusat perdagangan di Selat Malaka sekaligus Kerajaan Budha terbesar di Indonesia. Alasan mengapa para pedagang Arab Hadrami memilih Sriwijaya sebagai mitra dalam hal perdagangan tersebut dikarenakan Sriwijaya memiliki kekuatan secara hukum terkait dengan kebijakan perdagangan yang dianggap menguntungkan bagi para pedagang Keturunan Arab Hadrami di Indonesia.

Namun sempat mengalami kemunduran akibat persaingan dengan para pedagang Tiongkok yang samasama memiliki kepentingan dagang di Selat Malaka sehingga sebagian mereka melanjutkan aktivitas perdagangan di Jawa dengan membentuk koloni di sekitar Pantai Utara Jawa. Kebiasaan Orang-Orang Hadrmi dalam membentuk koloni Baru sudah dilakukan sebagai suatu ciri khas mengenai identitas serta asal usul budaya mereka. Aktivitas orang-orang Hadrami melakukan proses islamisasi di Jawa sehingga ketika Islam mulai berkembang di Jawa sangat berpengaruh terhadap perekonomian mereka dengan mengadakan kontak kerjasama dengan wedana pimpinan daerah yang saat itu Jawa di bawah kendali Majapahit.

Hingga Masa VOC Masyarakat Keturunan Arab Hadrami masih melakukan aktivitas perdangan namun ajak yang dibebankan dari VOC sangatlah tinggi sehingga sebagian dari mereka melakukan diaspora kembali ke Malaka dan melakukan hubungan dagang dengan Kesultanan Malaka. Sebagian lainnya lebih menetap di Jawa dan mengikuti aturan VOC. VOC berakhir karena tingkat korupsi merajalela pada tahun1799 akibat kehabisan kas dagang sebagai akibat korupsi yang dilakukan oleh para pejabat. Terbentuklah Masa Pemerintah Hindia Belanda yang diawali dengan Kebijakan Politik Etis. Saat itu Keturunan Arab Hadrami mendapatkan keuntungan dari kebijakan tersebut dikarenakan diberikan akses perdagangan secara bebas oleh Pemerintah Hindia Belanda dan secara status sosial mereka mendapatkan posisi kelas dua dengan kategori Golongan Timur Asing yang berbeda dengan golongan Bumiputra yang menempati golongan terendah. 
Kemudian Masa Pergerakan membawa angin segar bagi Keturunan Arab Hadrami di Indonesia Deklarasi kebangsaan yang dikandangkan oleh berbagai organisasi pemuda dalam Sumpah Pemuda 28 Oktober 1928 yang mana dapat melintasi batas-batas etik dan agama berpengaruh pada orientasi kebernegaraan komunitas "Arab" di Indonesia. Deklarasi ke-Indonesian yang meliputi identitas teritorial, kesejarahan, bahasa, budaya, hak dan kewajiban serta kebangsaan mengintegrasikan semua etik pribumi dalam sebuah identitas tunggal yang menjadi pemandu arah dalam kehidupan berbangsa dan bernegara. Disadari atau tidak, deklarasi kebangsaan ini menimbulkan kesulitan bagi komunitas keturunan Arab karena status hukum mereka sebagai orang asing dengan orientasi kebernegaraan pada negeri yang amat jauh yaitu Hadramaut. Akan tetapi, secara kultural mereka terikat dengan budaya lokal di mana mereka menetap. Atas tantangan inilah tercipta lah sebuah gagasan sebagai berupaya untuk menyatukan seluruh keturunan Arab dan mengajak seluruh ulama maupun para pemuda keturunan Arab untuk menyatakan sebuah deklarasi "Sumpah Pemuda Keturunan Arab" pada tanggal 4 Oktober 1928 di Semarang.

\section{Munculnya Gerakan Pan-Islamisme Sebagai Semangat Awal Pembentukan Pendidikan Islam dan Identitas Ke-Araban}

Permulaan Abad XIX titik tolak pertemuan antara semangat nasionalisme dengan gerakan ke-Islaman dalam hal pembentukan orientasi negara. Bangsa Indonesia telah mengalami penderitaan akibat penjajahan mulai awal abad ke-17 sampai abad ke-20.. Perlawanan sebelum Masa Pergerakan Nasional hanya bersifat kedaerahan dengan cara memandang yang kolot tentang munculnya Ratu Adil sebagai usaha menyelamatkan masyarakat atas tindakan yang dilakukan oleh Kolonial. Namun pada umumnya bentuk perlawanan semacam itu mengalami kegagalan. Akibat kegagalan demi kegagalan itu, maka mulai awal abad ke-20 lahir pemikiran untuk mengubah strategi perjuangan dari perjuangan yang dilakukan sebelumnya. Kemudian lahir sistem perjuangan baru yang dikenal dengan kebangkitan nasional. Dengan adanya pergantian strategi perjuangan dalam melawan sistem Pemerintah Kolonial Belanda akhirnya bangsa Indonesia berhasil mewujudkan persatuan dan kesatuan bangsa untuk menghancurkan sistem Pemerintah Kolonial. Salah satu bentuk perjuangan baru yakni melalui pembentukan organisasi-organisasi modern. Organisasi-organisasi yang dibentuk memiliki dua sifat yakni sifat kooperatif dan non kooperatif, artinya kedua sifat tersebut sama-sama memiliki peranan penting dalam memperjuangkan Kemerdekaan Indonesia. Dalam perjuangan mencapai kemerdekaan, bangsa Indonesia menempuh melalui berbagai bidang yaitu bidang budaya, sosial, ekonomi, dan politik. Di antara bidang-bidang tersebut, bidang politik yang paling menonjol, karena penjajah belanda menggunakan politik dalam segala bidang. Hal ini terjadi pada awal abad ke-20, pada waktu itu bangsa Indonesia telah mengubah cara perjuangannya, tidak lagi bersifat lokal, melainkan bersifat nasional. Dalam perjuangan bersifat nasional itu, peran organisasi sangat menentukan. Perjuangan tidak hanya dilakukan oleh kalangan politikus dan kelompok nasionalis dari kalangan bumiputra melainkan kelompok-kelompok Islam dan kelompok non bumiputera. Kelompok Islam kemudian banyak melakukan aktivitas perjuangan melalui bidang pendidikan dan tidak sedikit darinya yang berjuang melalui bidang politik. Masa Pergerakan Nasional juga dikenal sebagai Masa Pan-Islamisme di Indonesia yang mana pola gerakan yang dibangun oleh organisasi yang berorientasikan dengan ideologi Islam hampir sama yang dibawakan oleh Gerakan Pan-Islamisme di Timur Tengah. Di sisi lain pada periode yang sama terjadinya gerakan Pan-Arabisme di Timur Tengah yang membawa semangat kelompokkelompok terutama Keturunan Arab dalam mewujudkan rasa persaudaraan kelompok Arab Hadrami dalam bingkai Nasionalisme di Indonesia.

Di Hindia Belanda kemunculan gagasan Pan-Islamisme muncul setelah didirikannya Jami'at AlKhairiyyah atau lebih lebih dikenal sebagai Organisasi Jamiat Kheir adalah sebuah organisasi pendidikan yang berorientasi Gerakan Pan-Islamisme melalui pola Tarbiyah (pendidikan). Organisasi Jamiat Kheir mulanya didirikan di Pekojan Jakarta. Kekhawatiran Pemerintah Hindia Belanda dalam mendirikan organisasi pendidikan dikarenakan adanya stigma dari Pemerintah Hindia Belanda bahwa nantinya organisasi pendidikan tersebut akan memasuki ranah politik seperti organisasi pergerakan lainnya yang bermula dari organisasi pendidikan. Berkat usaha yang dilakukan oleh para pendiri Jamiat Kheir akhirnya mendapatkan persetujuan Pemerintah Hindia Belanda dengan menjadikan Jamiat Kheir sebagai lembaga pendidikan resmi yang diakui oleh Pemerintah Hindia Belanda pada tahun 1909. Organisasi ini didirikan oleh Kelompok Masyarakat Arab Hadrami Totok yang mana secara nasab memiliki garis keturunan langsung dengan leluhur mereka dari Hadramaut Yaman. Kebudayaan yang dianut nya mengacu pada kebudayaan Hadramaut Yaman berbeda hal dengan Kelompok Arab Peranakan yang sudah berbaur melalui pernikahan dengan Masyarakat Pribumi. Mengenai orientasi tentu jelas kebanyakan dari golongan Sayyid sangat menghendaki Bentuk Pemerintahan Hindia Belanda sebagai negara yang sah. Akan tetapi Ahmad Sukrati salah satu anggota Jami'at Kheir dan sekaligus pendiri Al-Irsyad sangat tidak setuju dengan orientasi identitas yang diagungkan oleh Kelompok Masyarakat Totok sehingga Ahmad Sukrati 
memutuskan untuk keluar dari Jamiat Kheir dan mendirikan lembaga pendidikan Al-Irsyad sebagai bentuk nasionalisme sekaligus representatif dari simbol 'perlawanan' bagi Kelompok Arab Peranakan.

Akan tetapi dikalangan masyarakat Hindia Belanda kedua gagasan tersebut dapat diterima dengan baik dikalangan masyarakat bahkan akademisi. Bukti bahwa hubungan Islam-Nasionalis bermula ketika Snouck Hurgronje seorang oriantalis memiliki kedekatan dengan Sayyid Utsman seorang Keturunan Arab Hadrami yang menetap di Hindia Belanda pada tahun 1890. Kedekatan antara Sayyid Utsman dengan Snoouck terjadi ketika Sayyid Utsman membantu dalam menyusun thesis dengan menerjemahkan ke dalam Bahasa Melayu dan Jawa yang dikerjakan oleh Snouck untuk mempelajari perilaku Masyarakat Islam di Hindia Belanda. Persahabatan Snouck dengan Sayyid Utsman mengantarkannya Snouck untuk mempelajari Ajaran Islam secara penuh. Menjelang tahun 1920 ketika Snouck ditugaskan di Aceh dalam tugas untuk mempelajari Masyarakat Aceh yang kemudian dimanfaatkan oleh Pemerintah Hindia Belanda untuk menguasai Kerajaan Aceh sebagai benteng pertahanan terakhir dalam peperangan melawan Kolonialisme dan Imperialisme, hubungan Snouck dengan Sayid Utsman masih memiliki kedekatan (Koningsvled. 1989, hlm. 194).

Beberapa tahun setelahnya tahun 1928 menjadi awal dari Gerakan Sumpah Pemuda yang selama masamasa pergerakan munculnya berbagai organisasi-organisasi pergerakan nasional yang berorientasi pada gagasan Nasionalis. Terdapat kelompok Islam salah satunya Jong Islamiten Bond bentukan Mochammad Tabrani (Somad, 2015, hlm. 3). Momen Gerakan Sumpah Pemuda kemudian diikuti oleh Sekelompok Arab Hadrami dalam melakukan 'Sumpah Keturunan Arab' di Indonesa yang digagas oleh Abdurahman Baswedan seorang nasionalis Keturunan Arab Peranakan. Deklarasi Sumpah Keturunan Arab di Indonesia dilakukan pada tahun 1929 satu tahun setelah Sumpah Pemuda. Abdurahman Baswedan sebelumnya diundang sebagai tamu undangan oleh Soegondo Djodjopoespito sebagai ketua pelaksana Sumpah Pemuda yang sekaligus sebagai Ketua Perhimpunan Pelajar-Pelajar Indonesia (PPI). Maka pada tahun 1930 didirikannya PAI (Partai Arab Indonesia) sebuah organisasi yang bergerak pada masalah sosial-budayapolitik bagi Keturunan Arab di Indonesia (Kartodirdjo. 2015, hlm. 133). PAI diketuai langsung oleh AR. Baswedan dengan merekrut beberapa anggota Keturunan Arab Peranakan untuk menjadi anggota PAI salah satunya yakni Hoesein Bagafieh yang ditempatkan menjadi wakil dari PAI. Akan tetapi PAI di Masa Kependudukan Jepang terpaksa dibubarkan karena sebagian bekas anggota PAI lebih terlibat pada perjuangan bawah tanah dan sebagian diantaranya sibuk merumuskan pembentukan dasar negara melalui Sidang BPUPKI (Hayaze, 2015, hlm. 135).

\section{Perkembangan Awal Lembaga Pendidikan Al-Irsyad.}

Lembaga pendidikan Al-Irsyad didirikan pada tanggal 6 September 1914 dengan nama lengkap Jami'yyah Al-Ishlah wal Irsyad al-Islamiyah atau yang lebih dikenal dengan Al-Irsyad. Lembaga ini didirikan pada mulanya sebagai kekecewaan Ahmad Sukrati dalam usaha untuk memajukan pendidikan bagi Masyarakat Keturunan dan Masyarakat Pribumi. Ahmad Sukrati merupakan asli Sudan yang merantau ke Batavia untuk kegiatan berdakwah. Ahmad Sukrati sempat bergabung menjadi anggota Jamiat Khier namun memutuskan untuk keluar karena perbedaan pandangan mengenai soal pendidikan. Pada awal pendirian Pendidikan Al-Irsyad didirikannya sebuah madrasah di Mangga Besar Batavia. Sistem penerimaan murid yang belajar pada mulanya hanya menerima dari kalangan Masyarakat Arab Peranakan akan tetapi lamban laun sudah membuka diri dengan menerima masyarakat setempat. Kurikulum yang dibuat sangat mengacu kepada ajaran Islam dan mengadopsi dari sistem pendidikan Salafiyyah (Tradisional) seperti hal yang diterapkan pada pondok pesantren . Prinsip pendidikan yang diterapkan pada Lembaga Pendidikan Al-Irsyad mengacu pada pendidikan wathoniyah artinya pendidikan yang juga mengajarkan tentang asal usul leluhur Masyaraka Keturunan Arab Hadrami dan juga mengajarkan cinta terhadap tanah air. Namun penerapan sistem pendidikan ini tidak berlangsung lama seiring dengan dibukanya para pengajar dari kalangan pribumi untuk mengajarkan pendidikan Islam. Sosok Ahmad Sukrati selama menjadi guru dianggap oleh murid-muridnya sebagai sosok yang demokratis. Sehingga berkat usaha dari Ahmad Sukrati Al-Irsyad memberanikan diri untuk membuka cabang-cabang pendidikan yang tersebar di Pesisir Utara Jawa seperti Tegal, Semarang, dan Surabaya. Di Surabaya jumlah kelompok Hadrami yang menempati struktural cabang daerah sangat dominan dibandingkan daerah-daerah lain yang memiliki keanggotaan mayoritas warga pribumi.

Pada tahun 1922 diperkenalkan nya Bahasa Melayu bagi pelajar pribumi sebagai Bahasa Pengantar dalam melaksanakan kegiatan belajar mengajar di Al-Irsyad. Pengenalan Bahasa Melayu kemudian di respon positif oleh Abdurahman Baswedan yang sekaligus murid Al-Irsyad. Proses pendidikan Al-Irsyad sejak awal telah menanamkan kepada para muridnya untuk menjadi pribadi yang merdeka, dan telah memberikan persamaan sederajat selama mengikuti proses pendidikan di Al-Irsyad. 
Tidak ada perbedaan khusus bagi murid pribumi dan murid Keturunan Arab Hadrami semuanya sederajat dan berhak mendapatkan perlakuan yang sama dalam mengenyam pendidikan di Madrasah AlIrsyad (Malik, 2019, hlm. 71). Abdurahman Baswedan sangat menghormati sosok Ahmad Sukrati sekaligus menjadi sosok yang dipercaya oleh Ahmad Sukrati dalam mengembangkan Sistem Pendidikan Al-Irsyad setelah lulus dari sekolah tersebut. Kedekatan Abdurahman Baswedan dengan Ahmad Sukrati ketika sosok Abdurahman Baswedan sering berdiskusi dengan Ahmad Sukarti mengenai masalah nasionalisme dan identitas kebangsaan. Kesuksesan Lembaga Pendidikan Al-Irsyad merupakan keberhasilan ketiga tokoh dalam mendirikan Al-Irsyad diantaranya Ahmad Dahlan, Ahmad Hassan, dan Ahmad Sukrati. Ketiga tokoh dikenal sebagai 'trio Ahmad' dan 'trio pembaharu Islam'. Ahmad Dahlan yang saat itu juga merupakan Ketua dari Muhammadiyah dan satu-satunya petinggi Al-Irsyad yang berasal dari kalangan pribumi membantu demi terwujudnya 'pendidikan yang merdeka'. Wujud nyata dari kepedulian Ahmad Dahlan yakni dengan menyekolahkan sebagian muridnya untuk belajar di Al-Irsyad. Sedangkan Ahmad Hassan merupakan tokoh dalam pendirian Al-Irsyad namun Ahmad Hassan juga mendirikan organisasi Islam yang berorientasikan pada bidang politik maka pada tahun 1926 dibentuk lah organisasi Persis (Persatuan Islam).

\section{Misi Pendidikan Al-Irsyad}

Sejak awal didirikannya Lembaga Pendidikan Al-Irsyad sangat mengutamakan pada aspek pendidikan dengan mempromosikan masalah identitas ke-Hadramiannya. Organisasi Perhimpunan Al-Irsyad memiliki misi untuk mengajarkan nilai-nilai ke-Islaman serta memberikan pelayanan pada masyarakat dalam bidang sosial sama halnya dengan organisasi Jamiat Kheir yang sudah terlebih dahulu didirikan sehingga Al-Irsyad tidak terlibat pada kegiatan politik praktis meskipun pada perkembangan selanjutnya murid Al-Irsyad banyak terlibat pada gerakan politik. Sistem pendidikan yang dibangun oleh Al-Irsyad dibuat dengan sistem sekolah secara terpisah. Tujuan dari dipisahkannya sistem sekolah secara terpisah agar dibebaskannya siswa dalam memperkenalkan sekaligus mengedukasi budaya Masyarakat Hadrami dalam membentuk semangat nasionalisme yang mengacu pada budaya 'Hadramaut'. Al-Irsyad kemudian membentuk sistem pendidikan klasikal dengan total masa belajar kurang dari 15 tahun. Jenjang pendidikan Al-Irsyad dibagi berdasarkan tingkat usianya diantaranya (Thalib, 2018, hlm. 8). Pertama, Auwaliyah dan Ibditaiyah (sebagai tingkat pendidikan dasar) dengan durasi pendidikan 7 tahun. Kedua, Tajhiziyah dan Mu'alimin (sebagai tingkatan pendidikan menengah) dengan durasi pendidikan selama 6 tahun. Ketiga, Takhassus (sebagai tingkatan tinggi) dengan durasi pendidikan selama dua tahun.

Dalam konteks pembagian materi yang diajarkan Lembaga Pendidikan Al-Irsyad mengajarkan Bahasa Arab dan Pelajaran Sejarah sebagai mata pelajaran yang wajib diajarkan. Kedua mata pelajaran tersebut yang diajarkan mulanya sebagai bentuk kesadaran akan tradisi dan nasal usul nenek moyangnya. Misi dari pembentukan Al-Irsyad berusaha untuk membentuk kemampuan daya berpikir kritis tanpa ditempa cara berpikir yang konservatif atas dogma. Al-Irsyad berhasil memobilisasi para tokoh yang di dalamnya untuk menumbuhkan semangat jiwa nasionalisme seperti apa yang dicita-citakan oleh Ahmad Sukrati sebagai pembentuk pola pendidikan yang merdeka (Hasyim \& Haryono, 2019, hlm. 167).

Ketika didirikannya PAI (Partai Arab Indonesia) banyak murid-murid Al-Irsyad bergabung dalam pembentukan partai tersebut. Namun sebagian lainnya enggan untuk bergabung pada organisasi tersebut dengan masalah perbedaan orientasi yang hanya berfokus pada masalah ke-Islaman. Maka, ketika Ahmad Hassan mendirikan Organisasi Persatuan Islam (PERSIS), sebagian murid yang enggan masuk ke PAI lebih memilih untuk bergabung ke organisasi tersebut. Kedua organisasi tersebut baik PAI maupun PERSIS memiliki bentuk orientasi politik yang berbeda. PAI lebih mengutamakan semangat nasionalisme, sedangkan PERSIS sangat mengedepankan ideologi Islam. Bahkan Hassan Al Banna sempat berdebat dengan Soekarno ketika keduanya sedang mengadakan diskusi terbuka di Bandung tahun 1924. Soekarno saat itu menjadi mahasiswa teknik sipil di ITB sedangkan kedatangan Ahmad Hassan ke Bandung pada mulanya untuk mempelajari produksi kain tenun di Bandung. Tema yang diperdebatkan yakni masalah pembentukan negara sekuler dalam pemerintahan. Ahmad Hassan tentunya sangat menentang pembentukan negara sekuler sedangkan Soekarno sangat mendukung pembentukan dengan identitas keIndonesiaan yang dicita-citakan pada Organisasi PNI (Partai Nasional Indonesia) (Choirunnnniswah, 2013, hlm. 68).

\section{Al-Irsyad Masa Kependudukan Jepang}

Ketika tahun 1937 organisasi MIAI (Majelis A'la Indonesia) didirikan, oleh K.H. Mas Mansur dan K.H. Wahab Chasbullah, banyak organisasi yang berorientasi sosial pendidikan dan islam bergabung untuk menjadi anggota MIAI, termasuk Al-Irsyad yang ikut bergabung menjadi MIAI. Terdapat kesamaan antara MIAI dengan Al-Irsyad yang mana keduanya tidak berorientasi pada organisasi politik, Namun pada tahun 1939 kiprah MIAI berubah haluan menjadi suatu organisasi politik yang mana ketika bergabung menjadi anggota GAPI yang menuntut untuk berparelemen. MIAI memutuskan untuk bergabung dengan GAPI, 
sebagai syarat GAPI harus menerima kehadiran kelompok Islam dan menerima Syariat sebagai dasar yang jelas dalam hal pemerintahan. Maksud dukungan MIAI untuk memperjuangkan Indonesia berparlemen dengan bersandarkan pada hukum Syariat yang mana sistem pemerintahan yang diatur harus berlandaskan Islam. Meskipun tidak semua cita-cita yang diharapkan oleh MIAI tercapai, tetapi jelas terlihat bahwa MIAI mempunyai peran dalam usaha mempersatukan umat Islam melalui perserikatan organisasi-organisasi Islam. khususnya dan bangsa Indonesia umumnya. Pendirian MIAI kemudian mendapatkan restu Pemerintah Kolonial Belanda (Miftahuddin, 2017, hlm. 7).

Namun ketika kehadiran Jepang pada tahun 1942 MIAI tidak berjalan dengan lama. Organisasi tersebut dibubarkan oleh Jepang karena dianggap sebagai 'colonial agent' dan digantikan dengan MASYUMI (Majelis Syuro Umat Muslimin Indonesia). Hal tersebut berdampak pada organisasi Al-Irsyad yang juga ikut dibubarkan oleh Jepang. Namun sebelum dibubarkan nya Masa Kependudukan Jepang, Al-Irsyad sudah menuntut agar terbentuknya MIAI baru pada sidang konferensi besar MIAI. Kemudian, Al-Irsyad terpaksa menutup cabang-cabangnya yang hampir tersebar di Pulau Jawa dan sebagian Sumatera.

Komunitas Hadrami dalam gerakan Al-Irsyad pada periode Masa Kependudukan Jepang hingga Masa Revolusi Kemerdekaan Indonesia mengalami masa-masa sulit. Banyak anggota dari Al-Irsyad yang kemudian keluar dari Al-Irsyad dan lebih fokus kepada bidang perniagaan. Banyak dari mereka yang kemudian membuka lapak-lapak baju di wilayah Tanah Abang dan Mangga Besar. Akan tetapi sebagian mereka justru tergabung dalam Laskar Hisbullah pimpinan K.H. Wahab Hasbullah mantan pendiri MIAI yang jug ikut memperjuangkan Kemerdekaan Indonesia di Surabaya sehingga meletusnya Peperangan 10 November 1945.

\section{Kondisi Al-Irsyad Sampai Tahun 1950}

Ketika Masa Mempertahankan Kemerdekaan Indonesia atau lebih dikenal dengan Masa Revolusi Kemerdekaan Indonesia, Al-Irsyad ditutup dan banyak kader dan anggota Al-Irsyad ikut berperang dalam menghadapi Masa Kemerdekaan Indonesia. Tahun 1949 Al-Irsyad dihidupkan kembali setelah mengalami masa vacuum hampir 6 tahun. Pengaktifan kembali organisasi Al-Irsyad dilakukan Muktamar Al-Irsyad ke-27 di Pekalongan pada tahun 1949 dalam rangka reorganisasi dan rehabilitasi Organisasi Al-Irsyad sebagai organisasi yang memiliki orientasi pada bidang pendidikan dan sosial. Abdurahman Baswedan kemudian memimpin Al-Irsyad dengan memasukkan kurikulum baru menjadikan Bahasa Indonesia sebagai bahasa pengantar. Selama gaya kepemimpinan Abdurahman Baswedan status Al-Irsyad sudah dinaungi oleh Kementerian Pendidikan sehingga kurikulum yang semula mengajarkan wathoniyyah digantikan dengan kurikulum yang dibuat oleh pemerintah.

Partai-partai besar seperti Masyumi menjadikan Al-Irsyad sebagai bagian dari kadernya dengan menggerakkan massa simpatisan dari Al-Irsyad sedangkan para pengurus besar Al-Irsyad tidak terlibat pada bidang politik. Banyak pemuda Al-Irsyad yang bergabung ke GPII (Gerakan Pelajar Islam Indonesia) mereka mendukung Masyumi secara penuh dana-dana yang seharusnya dialokasikan untuk kepentingan Pendidikan Al-Irsyad disumbangkan untuk kepentingan Masyumi. Sehingga banyaknya anggota Al-Irsyad yang bergabung ke Masyumi menghambat upaya reorganisasi kembali organisasi tersebut. Sehingga berdampak pada kurangnya jumlah kader muda Al-Irsyad dan Al-Irsyad hanya dijalankan oleh pengurus senior dengan tidak lagi melibatkan peran pemuda Al-Irsyad (Padmo, 2012).

Pada tahun yang sama, AR. Baswedan bergabung dengan Partai Masyumi. AR. Baswedan menjadi pejabat tinggi partai Islam terbesar dalam sejarah Indonesia. Deliar Noer menyimpulkan bahwa AR. Baswedan termasuk dalam kelompok pendukung Moh. Natsir di Masyumi. Hingga akhirnya sosok pemersatu bangsa Arab itu meninggal pada usia 77 tahun pada 16 Maret 1986 di Jakarta dan jasa-jasa dalam upaya mempersatukan para Keturunan Arab semakin dikenang oleh Bangsa Indonesia khususnya Keturunan Arab di Indonesia.

Pada sejarah partai Masyumi, tekad untuk menjadikannya sebagai partai tunggal dalam Islam membuahkan dua jenis keanggotaan di dalam partai tersebut. Kedua jenis keanggotaan tersebut adalah anggota biasa dan anggota organisasi atau anggota istimewa. Syarat minimal usia 18 tahun untuk anggota perseorangan. Setiap anggota akan diberikan KTA (Kartu Tanda Anggota). Anggota istimewa Masyumi awalnya terdiri dari Muhammadiyah, NU, Perikatan Umat Islam dan Persatuan Umat Islam, dan Al-Irsyad. Jumlah anggota kemudian terus bertambah dan Masyumi tetap memperluas pengaruhnya dengan mendirikan berbagai organisasi yang sifatnya otonom seperti Serikat Tani Islam Indonesia (STII), Serikat Buruh Islam Indonesia (SBII) yang tujuannya untuk menyaingi keberadaan Serikat Buruh Komunis (SOSBI) juga pembentukan ranting-ranting hingga ke pedesaan. Pada 31 Desember 1950, Masyumi telah tercatat memiliki 237 cabang, 1080 anak cabang, 4982 ranting dan kurang lebih 10 juta anggota. Jumlah anggota yang besar dikarenakan pola pendekatan Masyumi yang berusaha untuk menggaet suara anak muda dengan pola tarbiyah dalam praktik yang diajarkan oleh Masyumi. 
Sehingga banyak kelompok pemuda Islam salah satunya kelompok Al-Irsyad yang tertarik dan memutuskan untuk bergabung menjadi anggota atau kader Masyumi. Sehingga dapat dikatakan hubungan antara Al-Irsyad dengan Masyumi seakan memiliki kedekatan secara politik meskipun sebenarnya AlIrsyad tetap berorientasi pada bidang pendidikan. Organisasi ini seakan kehilangan figure pasca meninggalnya Ahmad Sukrati dan arah orientasi yang jelas dalam perjalanan Lembaga Pendidikan AlIrsyad.

\section{KESIMPULAN}

Pembahasan peranan Kaum Hadrami dalam mendirikan Al-Irsyad memiliki peranan penting dalam Sejarah Pendidikan di Indonesia. Sejak awal didirikannya Al-Irsyad mereka selalu konsisten dalam berusaha memajukan pendidikan bagi masyarakat keturunan. Prinsip kemerdekaan sudah ditanam dan diajarkan bagi para pelajarnya sehingga menjadikan para alumnus Al-Irsyad memiliki orientasi kenegaraan dan kebangsaan serta sebagai upaya pembentukan rasa cinta tanah air. Jamiat Kheir sudah terlebih dahulu ada dengan memiliki berbagai fasilitas modern namun pola pendidikan yang diterapkan oleh Jamiat Kheir tidak mengedepankan masalah kesederajatan baik antara golongan Sayyid (Totok) maupun Alawiyyin (Peranakan). Maka sebab lah Syaikh Ahmad Sukrati keluar dari Jamiat Kheir dan kemudian mendirikan Al-Irsyad. Setelah tiga tahun berdiri, Perhimpunan Al-Irsyad mulai memberanikan untuk membuka cabangcabang di Pesisir Utara Jawa bahkan hingga di Bandar Aceh. Tiap cabang yang dibangun dalam bentuk madrasah karena Al-Irsyad menerapkan sistem pembelajaran secara terpisah. Cabang pertama di Tegal (Jawa Tengah) pada 1917, dimana madrasah nya dipimpin oleh murid Syekh Ahmad Surkati angkatan pertama, yaitu Abdullah bin Salim al-Attas.

Meskipun pada perkembangan selanjutnya hingga berlanjut pada Masa Reformasi internal Al-Irsyad mengalami perpecahan. Perpecahan tersebut dikarenakan sebagai buntut panjang Masa Orde Baru ketika mulai menerapkan Azas Tunggal Pancasila sebagai dasar mutlak dalam pelaksanaan praktik pendidikan yang diatur dalam P4 (Pedoman Penghayatan Pengamalan Pancasila). Panduan P4 dibentuk berdasarkan Ketetapan MPR no. II/MPR/1978. Tidak semua anggota kelompok Al-Irsyad mendukung P4 dikarenakan sebagian dari mereka menginginkan agar ideologi Islam sebagai ideologi kuat dalam melaksanakan program pendidikan hingga sampai politik praktis. Maka dampaknya Al-Irsyad terbagi menjadi dua yakni Al-Irsyad Baru yang didominasi oleh kelompok Salafi-Islami dengan kelompok Al-Irsyad Lama yang didominasi oleh kelompok Hadrami Tulen yang berjiwa nasionalisme. Saat ini Al-Irsyad Sejak didirikannya bertujuan memurnikan tauhid, ibadah dan amaliah Islam. Bergerak di bidang pendidikan dan dakwah. Untuk merealisasikan tujuan ini, Al-Irsyad sudah mendirikan ratusan sekolah formal dan lembaga pendidikan non-formal di seluruh Indonesia. Dan dalam perkembangannya kemudian, kegiatan Al-Irsyad juga merambah bidang kesehatan, dengan mendirikan beberapa rumah sakit. Pada bidang sosial lembaga Al-Irsyad sudah memiliki lembaga Amil Zakat yang akan disumbangkan bagi masyarakat Kurang Mampu yang dilakukan melalui program zakat fitrah dan pembagian daging kurban setiap Bulan Suci Ramadhan.

\section{REFERENSI}

Anthias. (1998) Evaluating 'Diaspora': Beyond Ethnicity? [Online]. Sociology Volume 32 Nomor 3, 576

Choirunniswah. (2013). Organisasi Islam dan Peranannya Dalam Pendidikan Islam di Indonesia. Jurnal Ta'dib Volume XVIII No. 1, 56-84

Dja'far, A. (2018). Intolernnsi: Memahami kebencian \& kekerasan atas nama agama. Jakarta: Elex Media Komputindo

Djoened, Marwati, dkk, (1992). Sejarah Nasional Indonesia Jilid 2. Jakarta: Balai Pustaka

Haryono, P. \& Hasyim, Abdul, W. (2019). Jamiat Kheir dan Al-Irsyad: Kajian Komunitas Arab dalam Modernisasi Pendidikan Islam Awal Abad XX di Jakarta, [Online]. Volume 25 Nomor 2 Jurnal Buletin Al-Turas, 163-176

Hayaze, K. (2015). A.R. Baswedan Revolusi Batin Sang Perintis. Kumpulan Tulisan dan Pemikiran. Jakarta: Mizan

Isnaeni, H. (2019). Awal Mula Datangnya Orang-orang Arab ke Nusantara [Online] diakses https://historia.id/agama/articles/awal-mula-datangnya-orang-orang-arab-ke-nusantara-DnEMo . 05 April 2020

Katordirdjo, S. (2015). Pengantar Sejarah Indonesia Baru: Sejarah Pergerakan Nasional Dari Kolonialisme Sampai Nasionalisme. Yogyakarta: Ombak

Koentjaraningrat. (1989). Sejarah Teori Antropologi I. Jakarta: Universitas Indonesia Press

Koningsveld. (1989). Snouck Hurgronje dan Islam. Bandung: Giri Mukti Pustaka

Malik, A. (2019). Jami’yah Al-Irsyad Al-Islamiyah (Napak Tilas Sejarah Pergulatan Identitas Kebangsaan 
Kaum Hadrami di Indonesia) [Tesis]. UPT Universitas Alauddin Makassar.

Miftahuddin. (2017). Dinamika Komunitas Diaspora Arab Hadrami Dalam Sejarah Gerakan Al-Irsyad. [Disertasi]. UPT Universitas Islam Negeri Yogyakarta.

Padmo, S. (2007). Gerakan Pembaharuan Islam di Indonesia dari Masa Ke Masa: Sebuah Pengantar.

[Online]. Volume 19 Jurnal Humaniora, 151-160

Somad, A. (2015). Pemikiran dan Pergerakan Pan-Islamisme Pada Awal Abad Ke-20. [Online]. Volume 1 Nomor 1 Jurnal Candrasangkala Pendidikan Sejarah dan Sejarah Universitas Sulten Ageng Tirtayasa, $1-23$

Thalib, D. (2018). Peranan Lembaga Keagamaan Al-Irsyad Dalam Pendidikan di Indonesia. [Online]. Volume XVI Jurnal Studi Pendidikan, 1-10 